\title{
Potential application of aminiotic stem cells in veterinary medicine
}

\author{
Carlos Eduardo Ambrósio ${ }^{\S}$, Jéssica Rodrigues Orlandin, Vanessa Cristina Oliveira, \\ Lina Castelo Branco Motta, Priscilla Avelino Ferreira Pinto, Vitória Mattos Pereira, \\ Letícia Ribeiro Padoveze, Rafael Garcia Karam, Alessandra de Oliveira Pinheiro
}

\author{
Department of Veterinary Medicine, Faculty of Animal Science and Food Engineering, University of São Paulo, Pirassununga, \\ São Paulo, Brazil.
}

\begin{abstract}
In regenerative medicine stem cell biology has become one of the most interesting and more often studied subject. The amniotic membrane is the innermost layer of the fetal membranes and is considered a potential tool to treat many pathologies. It is used because it can be collected from discarded fetal material and is a rich source of stem cells with high proliferation and plasticity ratio capable of proliferating and differentiate in vitro. We propose to elucidate the characteristics and potencial clinical application of cells derived of amniotic membrane in veterinary medicine.
\end{abstract}

Keywords: amniotic membrane, stem cells, therapy.

\section{Introduction}

Stem cells have a capacity for differentiation and self-renewal. The great interest in science by these cells occur due to its immunomodulatory factors and tissue repair that make possible the use in therapies and innovative treatments (Faita et al., 2016).

Several adult tissue are source of stem cells with therapeutic potential, such a adipose tissue (Zuk et al., 2002; Rada et al., 2011), bone marrow (Kastrinaki et al., 2008) and peripheral blood (Villaron et al., 2004). There is possible to use the fetal membranes as source too, such as amniotic membrane (AMSC) (Park et al., 2012), amniotic fluid (Perin et al., 2007; Steigma and Fauza, 2007; You et al., 2008) and placenta (Steigman an Fauza, 2007; Barlow et al., 2008).

The fetal membranes are essential for embryonic development, as they provide maternofetal exchange. It consists of four different membranes: amnion, chorion, the vitelline sac and the allantoic sac (Mossman, 1987). The amnion is the innermost layer of fetal membranes, and contains a thick basement membrane and an avascular stroma (Malak and Bell, 1994) it acts as an additional maternofetal barrier (Leiser and Kaufmann, 1994). Other potential studies involved embryo development and stem cell niches is also highlighted in our data in canines (Martins et al., 2011; Pieri et al., 2015; De Souza et al. 2018).

Amniotic membrane stem cells (AMSC) have previously been described for their immunoregulatory properties (Bossolasco et al., 2006), their differentiate and self-renew potential (Kita et al., 2010) and vigorous cell proliferation. The AMSC are isolated from different species as canine, feline, equine, suine, murine and humans. The application of AMSC occur especially in dogs (Park et al., 2012; Cardoso et al., 2016) and the cats (Vidane et al., 2017), although the murine and suine are good specie models for humans studies.

Thus, this study aimed to carry out amniotic stem cells review about their applicability in the treatment in veterinary medicine.

\section{Stem cells lineages}

Discovered by Becker et al. (1963), the stem cells are undifferentiated cells able to perform selfrenewal and differentiate into the most diverse functional cell types (Park et al., 2015; Dai et al., 2016; Sobhani et al., 2017), thus being considered promising sources for the use in tissue engineering and organ regeneration.

Stem cells can be classified according to their potential for differentiation. Totipotent cells are those able to differentiate in all cell lines, including extraembryonic tissues, examples of totipotent cells include the zygote and its early cleavage products. The pluripotent cells are those capable of differentiating only in cells belonging to the three germ layers (Morgani et al., 2013) as embryonic stem cells (ESCs) (Slack, 2018) and induced pluripotent stem cells (iPSCs), somatic cells reprogramed do pluripotency (Takahashi and Yamanaka 2006). The iPSCs were initially produced of cells of mice and humans, however, there is currently reprogramming cells several animal species (Takahashi and Yamanaka, 2006; Takahsshi et al., 2007; Zhang et al., 2015; Gonçalves et al., 2017). Thus, besides the great importance for studies with a therapeutic objective, the IPSCs are also important in veterinary medicine for the maintenance of genetic material of animals with great economic importance (Kumar et al., 2015).

Another type of classification are the multipotent cells, which have ability to differentiate into all cell types within a given lineage (Ratajczak et al., 2014; Khanlarkhani et al, 2016). Although multipotent cells have a lower potential for differentiation, they are considered an important source for cellular therapy (Mirzaei et al., 2018), since they have genetic stability, low immunological profile and slower metabolism when compared to pluripotent stem cells, characteristics that decrease the risk of rejection (Liao and Tse, 2013). A further advantage of multipotent stem cells is the accessibility, and the fact that they can be isolated from the most diverse cell types (Khanlarkhani et al., 2016; Mirzaei et al., 2018). 
The mesenchymal stem cell (MSC) is a type of multipotent stem cell present in most adult tissues, a heterogeneous cell that plays a key role in the development and renew of organs (Klein, 2016). Several reports have shown that MSCs are commonly isolated and characterized from adipose tissue, bone marrow, umbilical cord, liver, as well a fetal attachments such as yolk sac and amnion (Seo et al., 2009; Uranio et al., 2011; Wenceslau et al., 2011; Reich et al., 2012; Mançanares et al., 2015). This adaptability and easy access make this stem cell a great candidate for use in transplants and therapies.

\section{Mesenchymal stem cells}

The MSCs were described by Friedenstein et al. (1970) in bone marrow as a component of the marrow stromal cell population that collectively supports hematopoietic stem cell renew and differentiation (Largeault, 2004; Martins et al., 2007). There are MSC niches in many adult tissues and organs. These cells play an active role in the homeostasis of these sites and can be isolated from the umbilical cord blood and matrix, adipose tissue, synovial membranes and embryonic and extraembryonic tissues.

According to the International Society of Cell Therapy the criteria for the characterization of human MSC are adherence to the plastic, positive expression for the surface markers CD105, CD73 and CD90, negative expression for the markers CD45, CD34, CD14 or CD11b, CD79a or CD19 and the HLA-DR surface molecules, capability to differentiate (osteoblasts, adipocytes and chondrocytes) in vitro (Dominici et al., 2006). According to Casteilla et al. (2011), Tharasanit et al. 2011), Mançanares et al. (2015), MSCs exhibit fibroblastoid morphology in culture.

MSC are easy to isolate, cultivate, and manipulate. These cells have immunoregulation and immunosuppressive characteristics, great plasticity and the potential for therapeutic applications for a variety of clinical conditions (Nardi and Meirelles, 2006; Oliveira et al., 2014; Samsoraj et al., 2017).

\section{Amniotic membrane}

The amnion is the most internal extraembrionary membrane, composed of a thin, elastic, translucent and semi-permeable membrane, derived from the ectoderm that covers the fetus and is closely connected to the chorionic membrane (Fernandes et al., 2012; Favaron et al., 2015).

Amniotic membrane (AM) is avascular tissue (Miglino et al., 2006; Dua et al., 2004). It has the function of involving the embryo and delimits the amniotic cavity, which is filled by amniotic liquid to avoid mechanic shocks (Moore and Persaud, 2008; Mamede et al., 2012; Koob et al., 2014).

Basically, the amniotic membrane is composed of two cell types. The epithelial layer composed by the epithelial amniotic cells which present a cuboidal/columnar morphology derived from ectoderm. And the second cell type is composed of mesenchymal stromal cells that are derived from mesoderm. Both populations have similar markers and have the potential to differentiate in vitro in the main mesodermal lineages (Chang et al., 2010; Díaz-Prado et al., 2011).

The AM has particular characteristics such as anti-inflammatory, anti-bacterial, anti-viral and immunological action. Also contains numerous growth factors, cytokines, and signaling molecules that play important roles in fetal development and gestation (Kogan et al., 2018).

Due to the multipotent properties, cells from the amniotic membrane have been investigated for being an attractive source for tissue transplantation (Mamede et al., 2012).

\section{Amniotic Membrane Stem Cells (AMSC)}

The AMSC are derived from extraembryonic mesoderm and are randomly distributed in the extracellular matrix of amnio which are rich in collagen and laminin fibers. They are multipotent cells with characteristics that favor their use, such as low immunogenicity and carcinogenicity, production of regulatory molecules of the immune system, high plasticity and propagation in culture and presence of high concentration of lysosomes (Chang et al., 2010; Cremonesi et al., 2011; Vidane et al., 2014; Cardoso et al., 2016; Faita et al., 2016; Magatti et al., 2016; Miki et al., 2016).

The AMSC demonstrates absent immunogenic properties and production of anti-inflammatory and bactericidal substances that provide their use in the treatment of skin wounds, cutaneous ulcers, and ophthalmic disorders such as corneal ulcers (Díaz-Prado et al., 2011; Parolini et al., 2008).

Furthermore, the AMSC are considered excellent sources of stem cells for regenerative therapies of the nervous system due to neural differentiation ability (Uranio et al., 2011; Park et al., 2012).

These cells have advantages over adult stem cells because they preserve embryonic, immunosuppressive and pluripotent characteristics, which are confirmed by the expression of embryonic markers such as OCT-4 and NANOG (Cremonesi et al., 2011; Vita et al., 2012; Saulnier et al., 2016). Other advantage of AMSC is because they are easy to acquire, offer no damage to donors, and have a lower immune response, making them important in research for regenerative medicine, since inflammation and immunogenicity are crucial factors for successful transplantation (Kim et al. 2014).

The cells derived from the amniotic membrane have the same characteristics of mesenchymal stem cells, according to the International Society of Cell Therapy criteria (Cardoso et al., 2016), and their morphology shows fibroblast characteristics (Fig. 1). 

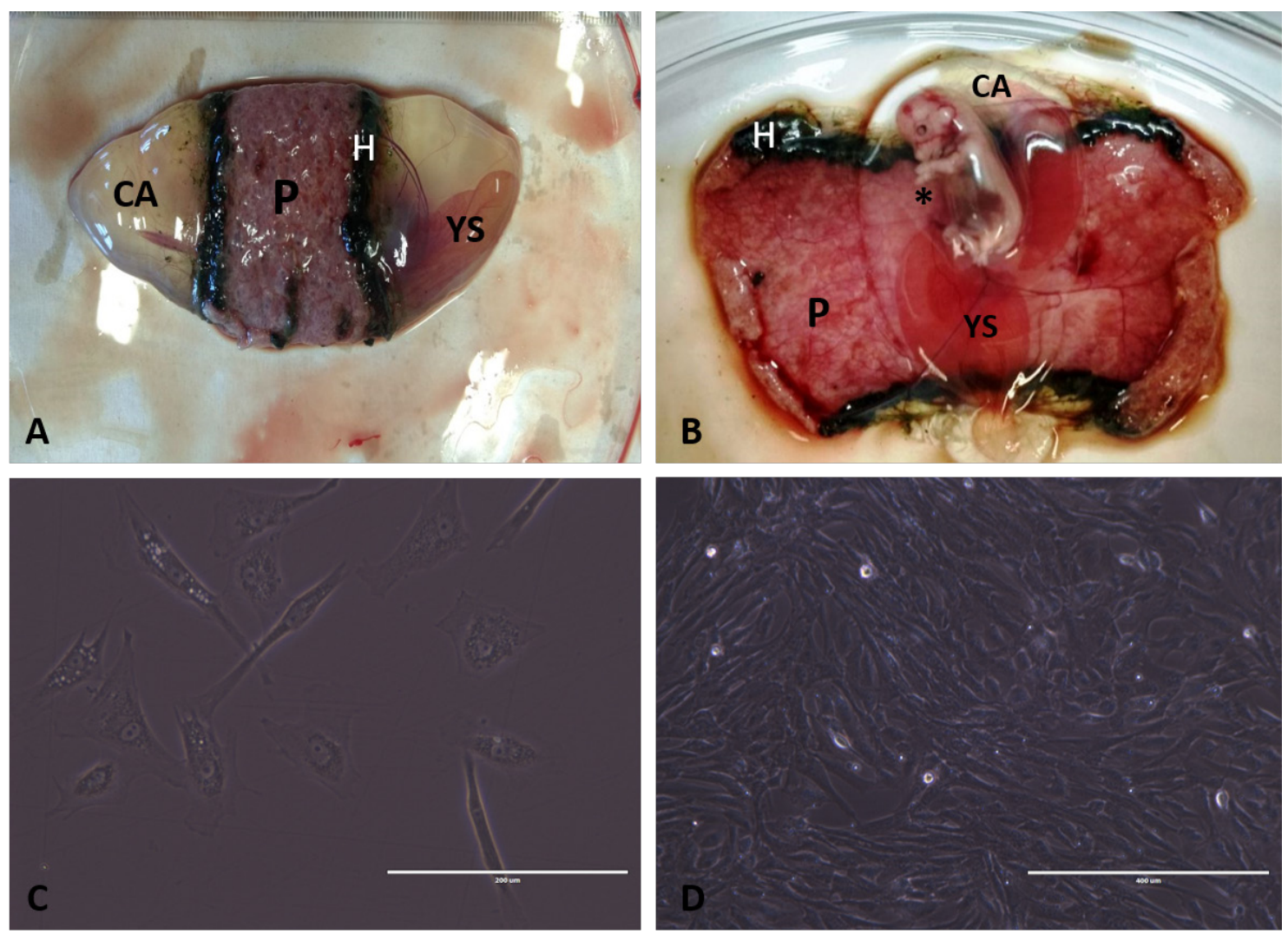

Figure 1. A and B: Canine fetus developing, with possible visualization of placental (P) structures, marginal hematoma $(\mathrm{H})$, chorioallantoic membrane (CA), yolk sac (YS) and amniotic membrane (*). C and D: photomicrographs of AMCs in primary culture on different days of culture. C, with 4 days and D with 10 days.

\section{Isolation Protocols for AMSC}

There are many types of isolation protocols for AMSC in each species, although they are quite similar. In this review, we will describe the protocols most use with different species in our lab.

For species which the site of collection is more contaminated, as swine and horses, we strongly suggest the refrigeration of samples $(1 \mathrm{~h}-2 \mathrm{~h})$ before the beginning of the mechanic process, in order to reduce the bacterial activity. So, the amniotic membrane must be mechanically dissect and isolated from embryonic attachments. Under sterile conditions, the tissue must be washed with PBS supplemented with $1 \%$ penicillin/streptomycin (P/S, Sigma, USA). After this step, the sample will be transfer to a clean dish and mince with scalpels to become homogeneous and pasty.

After the above-described process, the sample is submitted to chemical digestion using collagenase type I (Sigma, USA) which the concentration and time are described below to each species (Tab. 1).

After digestion the collagenase enzyme has to be neutralizing using the same volume of expansion media to the cell suspension. So, the digested sample is centrifuged at $1600 \mathrm{rpm} / 5 \mathrm{~min}$, and then cell pellet is obtained to be culture with the expansion media and keep at $37^{\circ} \mathrm{C}$ and $5 \% \mathrm{CO} 2$.

Table 1. Culture protocols of AMSC from different species.

\begin{tabular}{|c|c|c|c|c|}
\hline Animal & $\%$ collagenase & Time & Expanded Medium & Reference \\
\hline Canine & $1-2 \mathrm{mg} / \mathrm{mL}$ & $3-4 h$ & $\begin{array}{l}\text { high-glucose Dulbecco's modified Eagle's medium } \\
\text { (HG- DMEM) }+10 \% \\
\text { SFB }+1 \% \mathrm{P} / \mathrm{S}+2 \mathrm{mM} \text { L-glutamine }\end{array}$ & Park et al., 2012 \\
\hline Feline & $1 \mathrm{mg} / \mathrm{mL}$ & $3 \mathrm{~h}$ & $\begin{array}{l}\text { HG-DMEM + } 10 \% \text { SFB + } 1 \% \\
\mathrm{P} / \mathrm{S}+2 \mathrm{mM} \text { L-glutamine }\end{array}$ & Vidane et al., 2017 \\
\hline Equine & $\begin{array}{l}0,93 \mathrm{mg} / \mathrm{mL} \\
+20 \mathrm{mg} / \mathrm{mL} \\
\text { DNAse }\end{array}$ & $3 \mathrm{~h}$ & $\begin{array}{l}\text { HG-DMEM }+10 \% \mathrm{SFB}+10 \mathrm{ng} / \mathrm{ml} \text { epidermal } \\
\text { growth factor }(\mathrm{EGF} ; \text { Sigma })+1 \% \\
\mathrm{P} / \mathrm{S}+0.25 \mu \mathrm{g} / \mathrm{ml} \text { amphotericin } \mathrm{B}+2 \mathrm{mM} \text { L-glutamine }\end{array}$ & $\begin{array}{l}\text { Lange-Consiglio, } \\
\text { et al., } 2013 \mathrm{a}\end{array}$ \\
\hline Swine & $\begin{array}{l}0,93 \mathrm{mg} / \mathrm{mL} \\
+20 \mathrm{mg} / \mathrm{mL} \\
\text { DNAse }\end{array}$ & $3 \mathrm{~h}$ & $\begin{array}{l}\mathrm{HG}-\mathrm{DMEM}+10 \% \mathrm{SFB}+10 \mathrm{ng} / \mathrm{mL} \text { EGF }+1 \% \\
\mathrm{P} / \mathrm{S}+0.25 \mu \mathrm{g} / \mathrm{ml} \text { amphotericin } \mathrm{B}+2 \mathrm{mM} \text { L-glutamine }\end{array}$ & $\begin{array}{l}\text { Lange-Consiglio } \\
\text { et al., } 2015\end{array}$ \\
\hline Human & $25 \mathrm{mg} / \mathrm{mL}$ & $1 \mathrm{~h}$ & $\mathrm{HG}-\mathrm{DMEM}+10 \% \mathrm{SFB}+1 \% \mathrm{P} / \mathrm{S}$ & Dizaji et al., 2017 \\
\hline
\end{tabular}




\section{Applications and clinical implications of amniotic stem cells in Veterinary Medicine: a pet market model}

\section{Neurologic applications}

The AMSC is considered a source of election to treat spinal cord injury. Sankar et al. (2003), showed good interaction of human amniotic membrane stem cells when applied in iatrogenic spinal cord injury in monkeys, and they observed a significant remyelination, as well as their ability to modulate the glial scar. And a similar study was performed by Zhi-Yuan et al. (2006) who observed a returning of motor function in the hind limbs of treated animals. Furthermore, Meng et al. (2008) studied the co-transplantation of AMSC with stem cells of neuronal origin in rats with chronic spinal cord injury. And again, the results demonstrated a significant locomotor improvement in addition to neuronal survival and differentiation.

Kakishita et al. (2003) verified that human amniotic epithelial cells secrete biologically active neurotrophins and can enhance the survival of dopamine neurons, being a promising therapeutic tool in Parkinson's disease. As well as Yang et al. (2009) who also observed a increasing of dopamine and its metabolic products in the striatum in rats with Parkinson's disease.

\section{Ischemic dysfunction}

Kim and Choi (2011) observed neovascularization in mouses suffering of limb ischemia. They administered intramuscularly hAMSCs on the leg whose femoral vessels were ligated. The blood flow recovery was significantly higher in the transplanted group, when compared with the control group, being an attractive source for the treatment of ischemic diseases.

And Tao et al. (2012) transplanted human amniotic membrane stem cells transfected with the brain derived neurotrophic factor (BDNF) into the brains of rats with induced stroke. This technique ameliorated the behavioral dysfunction and reduced the infarct volume, improving functional recovery.

\section{Musculoskeletal disorders}

The stem cell therapy is a routine treatment in horses, and the amnion plays an important role in this scenario. In mares with endometriosis, the AMSC cells were used because of their potential to improve cell replenishment based on gene expression profiling when low proliferation of uterine cells is associated to pregnancy failure in an in vivo study, showing lower rate of reinjury and faster resume to their activities (Corradetti et al., 2014). In tendon repair, the re-injury was lower in treatment with AMSC than compared with BM-MSC ascertained by ultrasonography (LangeConsiglio et al., 2013b). Still, biomaterials composed for amniotic membrane has attracted attention. They have being associated to better mechanical properties in tendons injuries, plus this membrane has been used to accelerate healing wounds (Violini et al., 2012; Hortensius et al., 2016).

\section{Others applications}

A promising use of large animal models must be done before clinical trial and confirm efficacy of therapy and controversial results must be followed (Gonçalves et al, 2014). Kamiya et al. (2005) showed efficacy in suppressing corneal inflammatory reactions, when topically applied human amniotic membrane culture supernatant in mices with induced corneal neovascularization.

Vidane et al. (2017) evaluated the effects of intravenous administration of allogeneic feline amniotic membrane stem cells in cats with naturally occurring chronic kidney disease. Despite the kidney architecture and morphology did not change during the treatment, the tranplantation showed renoprotective effect, improved renal function, delaying the progression of the disease and stabilizing the clinical condition of the animals.

And finally, the AMSC are described into application in humans to aid in treatment of cutaneous wounds, burns, and superficial ocular reconstruction (Ward and Bennett, 1984; Avila et al., 2001; Gomes et al., 2005).

\section{Acknowledgments}

This study was financed in part by the Coordenação de Aperfeiçoamento de Pessoal de Nível Superior - Brasil (CAPES) - Finance Code 001, CNPq and FAPESP (Process Number: 2017/21266-0.

\section{References}

Avila M, Espanha H, Moreno C, Pena C. 2001. Reconstruction of ocular surface with heterologous limbal epithelium and amniotic membrane in a rabbit model. Cornea, 20:414-420.

Barlow S, Brooke G, Chatterjee K, Price G, Pelekanos R, Rossetti T, Doody M, Venter D, Pain S, Gilshenan K, Atkinson K. 2008. Comparison of human placenta- and bone marrow-derived multipotent mesenchymal stem cells. Stem Cells Dev, 17:10951108.

Becker AJ, Mcculloch EA, Till JE. 1963. Cytological demonstration of the clonal nature of spleen colonies derived from transplanted mouse marrow cells. Nature, 197: 452-454.

Bossolasco P, Montemurro T, Cova L, Zangrossi S, Calzarossa C, Buiatiotis S, Soligo D, Soligo D, Bosari S, Silani V, Deliliers GL, Rebulla P, Lazzari L. 2006. Molecular and phenotypic characterization of human amniotic fluid cells and their differentiation potential. Cell Res, 16:329-336.

Cardoso M, Pinheiro AO, Vidane AS, Casals JB, de Oliveira VC, Gonçalves N, Martins DS, Ambrósio CE. 2016. Characterization of teratogenic potential and gene expression in canine and feline amniotic 
membrane-derived stem cells. Reprod Domest Anim, 52:58-64.

Casteilla L, Benard VP, Laharrague P, Cousin B. 2011. Adipose-derived stromal cells: their identity and uses in clinical trials, an update. World J Stem Cells, $3: 25-33$.

Chang YJ, Hwang, SM, Tseng, CP, Cheng FC, Huang SH, Hsu LF, Hsu LW, Tsai M. 2010. Isolation of mesenchymal stem cells with neurogenic potential from the mesoderm of the amniotic membrane. Cells Tissues Organs, 192:93-105.

Corradetti B, Corradetti B, Correani A, Romaldini A, Marini MG, Bizzaro D, Perrini C, Cremonesi C, Lange-Consiglio A. 2014. Amniotic membrane-derived mesenchymal cells and their conditioned media: potential candidates for uterine regenerative therapy in the horse. Plos One. 9:1-9.

Cremonesi F, Corradetti B, Lange-Consiglio A. 2011. Fetal adnexa derived stem cells from domestic animal: progress and perspectives. Theriogenology, 75:14001415.

Dai R, Wang Z, Samanipour R, Koo K, Kim K. 2016. Adipose derived stem cells for tissue engineering and regenerative medicine applications. Stem Cells International, 2016:1-19.

Díaz-Prado S, Muinõs-López E, Hermida-Gómez T, Cicione C, Rendal-Vázquez E, Fuentes-Boquete I, De Toro FJ, Blanco FJ. 2011. Human amniotic membrane as an alternative source of stem cells for regenerative medicine. Differentiation, 81:162-171.

Dizaji Asl K, Shafaei H, Soleimani Rad J, Nozad Ho. 2017. Comparison of characteristics of human amniotic membrane and human adipose tissue derived mesenchymal stem cells. World J Plast Surg, 6:33-39.

Dominici M, Le Blanc $K$, Mueller I, SlaperCortenbach I, Marini M, Krause D, Deans R, Keating A, Prockop DJ, Horwitz E. 2006. Minimal criteria for defining multipotent mesenchymal stromal cells. The international society for cellular therapy position statement. Cytotherapy, 8:315-317.

de Souza AF, Pieri NCG, Roballo KCS, Bressan FF, Casals JB, Ambrósio CE, Perecin F, Martins DS 2018. Dynamics of male canine germ cell development. PLoS One. 28:13(2):e0193026.

Dua HS, Gomes JA, King AJ, Maharajan VS. 2004. The amniotic membrane in ophthalmology. Surv Ophthalmol, 49:51-77.

Faita T, Silva VN, Sattin WR, Pinheiro AO, Ambrósio CE. 2016. Amniotic membrane: an alternative source of mesenchymal stem cells in several animal species [in Portuguese]. Pesq Vet Bras, 3:520525.

Favaron PO, Carvalho RC, Borghesi J, Anunciação ARA, Miglino MA. 2015. The amniotic membrane: development and potential applications - a review. Reprod Dom Anim, 50:881-892.

Fernandes RA, Wenceslau CV, Reginato AL, Kerkis I, Miglino MA. 2012. Derivation and characterization of progenitor stem cells from canine allantois and amniotic fluids at the third trimester of gestation. Placenta, 33:640-644.

Friedenstein AJ, Chailakhjan RK, Lalykina KS
1970. The development of fibroblast colonies in monolayer cultures of guinea-pig bone marrow and spleen cells. Cell Tissue Kinet, 3:393-403.

Gomes JAP, Romano A, Santos MS, Dua HS. 2005. Amniotic membrane use in ophthalmology. Curr Opin Ophthalmol, 16:233-240.

Gonçalves NJN, Bressan FF, Roballo KCS, Meirelles FV, Xavier PLP, Fukumasu H, Williams C, Breen M, Koh S, Sper R, Piedrahita J, Ambrósio CE. 2017. Generation of LIF-independent induced pluripotent stem cells from canine fetal fibroblasts. Theriogenology, 92:75-82.

Gonçalves NN, Ambrósio CE, Piedrahita JA. 2014. Stem cells and regenerative medicine in domestic and companion animals: a multispecies perspective. Reprod Domest Anim, 49(Suppl 4):2-10.

Hortensius RA, Ebens JH, Arley BA. 2016. Immunomodulatory effects of amniotic membrane matrix incorporated into collagen scaffolds. $J$ Biomed Mater Res 104:1332-1342.

Kakishita K, Nakao N, Sakuragawa N, Itakura T. 2003. Implantation of human amniotic epithelial cells prevents the degeneration of nigral dopamine neurons in rats with 6-hydroxydopamine lesions. Brain Res, 980:48-56.

Kamiya K, Wang M, Ichida S, Amano S, Oshika T, Sakuragawa N, Hori J. 2005. Topical application of culture supernatant from human amniotic epithelial cells suppresses inflammatory reactions in cornea. Exp Eye Res, 80:6771-6779.

Kastrinaki MC, Andreakou I, Charbord P, Papadaki HA. 2008. Isolation of human bone marrow mesenchymal stem cells using different membrane markers: comparison of colony cloning efficiency, differentiation potential, and molecular profile. Tissue Eng Part C Methods, 14:333-339.

Khanlarkhani N, Baazm M, Mohammadzadeh F, Najafi A, Mehdinejadiani S, Sobhani A. 2016. Multipotent stem cell and reproduction. J Stem Cells, 4:219-229.

Kim EY, Lee K-B, Kim MK. 2014. The potential of mesenchymal stem cells derived from amniotic membrane and amniotic fluid for neuronal regenerative therapy. BMB Rep, 47:135-140.

Kim HG, Choi OH. 2011. Neovascularization in a mouse model via stem cells derived from human fetal amniotic membranes. Heart Vessels, 26:196-205.

Kita K, Gauglitz GG, Phan TT, Herndon DN, Jeschke MG. 2010. Isolation and characterization of mesenchymal stem cells from the sub-amniotic human umbilical cord lining membrane. Stem Cells and Dev, 19:491-502.

Klein D. 2016. Vascular wall-resident multipotent stem cells of mesenchymal nature within the process of vascular remodeling: cellular basis, clinical relevance, and implication for stem cell therapy. Stem cell int, doi: 10.1155/2016/1905846.

Kogan S, Sood A, Granick MS. 2018. Amniotic membrane adjuncts and clinical applications in wound healing: a review of the literature. Wounds, 30:168-173.

Koob TJ, Lim JJ, Massee M, Zabek N, Denozière G. 2014. Properties of dehydrated human amnion/chorion 
composite grafts: implications for wound repair and soft tissue regeneration. $J$ Biomed Mater Res B Appl Biomater, 102:1353-62.

Kumar D, Talluri TR, Anand T, Kues WA. 2015. Induced pluripotent stem cells: Mechanisms, achievements and perspectives in farm animals. World $J$ Stem Cells, 7:315-328.

Lange-Consiglio, Corradetti B, Meucci A, Perego R, Bizzaro D, Cremonesi F. 2013a. Characteristics of equine mesenchymal stem cells derived from amnion and bone marrow: in vitro proliferative and multilineage potential assessment. Equine Vet J, 45:737-744.

Lange-Consiglio, Tassan S, Corradetti B, Meucci A, Perego R, Bizzaro D, Cremonesi F. 2013b. Investigating the efficacy of amnion-derived compared with bone marrow-derived mesenchymal stromal cells in equine tendon and ligament injuries. Cytotherapy, 15:1011-1020.

Lange-Consiglio, Corradetti B, Bertani S, Notarstefano V, Perrini C, Marini MG, Arrighi S, Bosi G, Belloli A, Pravettoni D, Locatelli V, Cremonesi F, Bizzaro D. 2015. Peculiarity of porcine amniotic membrane and its derived cells: a contribution to the study of cell therapy from a large animal model. Cloning Stem Cells, 17:472-483.

Largeault AF. 2004. Embryos, stem cells and cell therapies: philosophical and anthropological issues [in Portuguese]. Estud Av, 18:227-245.

Leiser R, Kaufmann P. 1994. Placetal structure: in a comparative aspect. Exp Clin Endocrinol, 102:122-34.

Liao SY, Tse HF. 2013. Multipotent (adult) and pluripotent stem cells for heart regeneration: what are the pros and cons? Stem Cell Res Ther, 4:151-162.

Magatti M, Vertua, E, Munari S, Aro M, Caruso M, Silini A, Delgado M, Parolini O. 2016. Human amnion favours tissue repair by inducing the $\mathrm{m} 1$-to-m 2 switch and enhancing $\mathrm{m} 2$ macrophage features. $J$ Tissue Eng Regen Med, 11:2895-2911.

Malak TM, Bell SC. 1994. Differential expression of the integrin subunits in human fetal membranes. $J$ Reprod Fertil Abbreviation, 102:269-276.

Mamede AC, Carvalho MJ, Abrantes AM, Laranjo M, Maia CJ, Botelho MF. 2012. Amniotic membrane: from structure and functions to clinical applications. Cell and Tissue Res, 349:447-58.

Mançanares CAF, Oliveira VC, Oliveira LJ, Carvalho AF, Sampaio RV, Mançanares AC, Souza AF, Perecin F, Meirelles FV, Miglino MA, Ambrosio CE. 2015. Isolation and characterization of mesenchymal stem cells from the yolk sacs of bovine embryos. Theriogenology, 84:887-898.

Martins DS, Ambrósio CE, Saraiva NZ, Wenceslau CV, Morini AC, Kerkis I, Garcia JM, Miglino MA. 2011. Early development and putative primordial germ cells characterization in dogs. Reprod Domest Anim. 46(1):e62-6.

Martins GR, Marinho RC, Bezerra-Junior RQ, Câmara LMC, Albuquerque-Pinto LC, Teixeira MFS. 2017. Isolation, culture and characterization of multipotent mesenchymal stem cells from goat umbilical cord blood. Pesq Vet Bras, 37:643-649.

Meng XT, Li C, Dong ZY, Liu JM, Li W, Liu Y, Xue
H, Chen D. 2008. Co-transplantation of bfgf-expressing amniotic epithelial cells and neural stem cells promotes functional recovery in spinal cord-injured rats. Cell Bio Int, 32:1546-1558.

Miglino MA, Ambrósio CE, Martins DS, Wenceslau CV, Pfarrer C, Leiser R. 2006. The carnivore pregnancy: the development of the embryo and fetal membranes. Theriogenology, 66:1699-1702.

Miki T. 2016. A rational strategy for the use of amniotic epithelial stem cell therapy for liver diseases. Stem Cells Transl Med, 5:405-409.

Mirzaei H, Sahebkar A, Sichani LS, Moridikia A, Nazari S, Nahand JS, Salehi H, Stenvang J, Masoudifar A, Mizaei HR, Jaafari MR. 2018. Therapeutic application of multipotent stem cells. J Cell Physiol, 233(4):2815-2823.

Moore KL, Persaud TVN. 2008. Placenta and fetal membranes [in Portuguese]. 8.ed. Rio de Janeiro: Elsevier. p.41.

Morgani SM, Canham MA, Nichols J, Sharov AA, Migueles RP, Ko MSH, Brickman JM. 2013. Totipotent embryonic stem cells arise in ground-state culture conditions. Cell Rep, 6:1954-1957.

Mossman HW. 1987. Vertebrate fetal membranes: comparative ontogeny and morphology, evolution, phylogenetic significance, basic functions, research opportunities. 1.ed. London: Rutgers University Press, p.383.

Nardi BN, Meirelles LS. 2006. Mesenchymal stem cells: isolation, in vitro expansion and characterization. Handb Exp Pharmacol, 174:249-82.

Oliveira VC, Souza AF, Cury FS, Perecin F, Martins DS, Ambrósio CE. 2014. Stem cells derived from bone marrow and preclinical trials in veterinary medicine. Rev Bras Ci Vet, 21:143-149.

Parolini O, Alviano F, Bagnara GP, Bilic G, Buhring HJ, Evangelista M, Hennerbichler S, Liu B, Magatti M, Mao N, Miki T, Marongiu F, Nakajima $\mathbf{H}$, Nikaido T, Portmann-Lanz CB, Sankar V, Soncini M, Atadler G, Surbek D, Takahashi TA, Redl H, Sakuragawa N, Wolbank S, Zeisberger S, Zisch A, Strom SC. 2008. Concise review: isolation and characterization of stem cells from human term placenta: outcome of the first international workshop on placenta derived stem cells. Stem Cells, 2:300-311.

Park D, Lim J, Park JY, Lee SH. 2015. Concise review: stem cell microenvironment on a chip: current technologies for tissue engineering and stem cell biology. Stem Cells Trans Med, 11:1352-1368.

Park SB, Seo SM, Kim SK, Kang SK. 2012. Isolation and characterization of canine amniotic membranederived multipotent stem cells. Plos One, 7(9):e44693.

Perin L, Giuliani S, Jin D, Sedrakyan S, Carraro G, Habibian R, Warburton D, Atala A, De Filippo RE. 2007. Renal differentiation of amniotic fluid stem cells. Cell Proliferation, 40:936-948.

Pieri N, Souza AF, Casals JB, Roballo K, Ambrósio CE, Martins DS. 2015. Comparative Development of Embryonic Age by Organogenesis in Domestic Dogs and Cats. Reprod Domest Anim. 50(4):625-631.

Rada T, Reis RL, Gomes ME. 2011. Distinct stem cells subpopulations isolated from human adipose tissue 
exhibit different chondrogenic and osteogenic differentiation potential. Stem Cell Rev and Rep, 7:64-76. Ratajezak MZ, Marycz K, Poniewierska-Baran A, Fiedorowicz K, Zbucka-Kretowska M, Moniuszko M. 2014. Very small embryonic-like stem cells as a novel development concept and the hierarchy of the stem cell compartment. Adv Med Sci, 59:273-280.

Reich CM, Raabe O, Wenisch S, Bridger PS, Kramer M, Arnhold S. 2012. Isolation culture and chondrogenic differentiation of canine adipose tissue and bone marrow derived mesenchymal stem cells - a comparative study. Vet Res Commun, 31:139-148.

Samsoraj RM, Raghunath M, Nucombe V, Hui JH, van Wijnen AJ, Cool SM. 2017. Concise review: multifaceted characterization of human mesenchymal stem cells for use in regenerative medicine. Stem Cells Transl Med, 6:2173-2185.

Sankar V, Muthusamy R. 2003. Letter to neuroscience role of human amniotic epithelial cell transplantation in spinal cord injury repair research. Neuroscience, 118:11-17.

Saulnier N, Loriaua J, Febrea M, Robert C, Rakic R, Bonte T, Buff S, Maddens S. 2016. Canine placenta: a promising potential source of highly proliferative and immunomodulatory mesenchymal stromal cells? Vet Immunol Immunopathol, 171:47-55.

Seo MS, Jeong YH, Park JR, Parksb, Rho KH, Kim HS, Yu KR, Lee SH, Jung KW, Lee YS, Kang KS. 2009. Isolation and characterization of canine umbilical cord blood-derived mesenchymal stem cells. J Vet Sci, 10:181-187.

Slack JMW. 2018. What is a stem cell? Wires Wev Biol, 7:1-15.

Sobhani A, Khanlarkhani N, Baazm M, Mohammadzadeh F, Najafi A, Mehdinejadiani S, Aval FS. 2017. Multipotent stem cell and current application. Acta Medica Iranica, 55:6-23.

Steigman SA, Fauza DO. 2007. Isolation of mesenchymal stem cells from amniotic fluid and placenta. Curr Protoc Stem Cell Biol, Chapter 1:Unit 1E.2. doi: 10.1002/9780470151808.sc01e02s1.

Takahashi K, Yamanaka S. 2006. Induction of pluripotent stem cells from mouse embryonic and adult fibroblast cultures by defined factors. Cell, 126:663-76.

Takahashi K, Tanabe K, Ohnuki M, Narita M, Ichisaka T, Tomoda K, Yamanaka S. 2007. Induction of pluripotent stem cells from adult human fibroblasts by defined factors. Cell, 131:861-872

Tao J, Ji F, Liu B, Wang F, Dong F, Zhu Y. 2012 Improvement of deficits by transplantation of lentiviral vector-modified human amniotic mesenchymal cells after cerebral ischemia in rats. Brain Res, 1448:1-10.

Tharasanit T, Phuticanit N, Wangdee C, Soontornvipart K, Tantrajak S, Kaewamatawong T, Suwimonteerabutr J, upaphol $\mathbf{P}$, Techakumphu $\mathbf{M}$. 2011. Differentiation potentials of canine bone marrow mesenchymal stem cells. J Vet Med, 41:79-86.

Uranio FM, Valentini L, Lange-Consiglio A, Caira M, Guaricci AC, Labbate A, Catachio CR, Ventura M, Cremonesi F, Dellaquila ME. 2011. Isolation, proliferation, cytogenetic and molecular characterization and in vritro differentiation potency of canine stem cells from foetal adnexa: a comparative study of amniotic fluid, amnion, and umbilical cord matrix. Mol Reprod Dev, 78:361-373.

Vidane AS, Pinheiro AO, Casals JB, Passarelli D, Hage M, Bueno RS, Martins DS, Ambrosio CE. 2017. Transplantation of amniotic membrane-derived multipotent cells ameliorates and delays the progression of chronic kidney disease in cats. Reprod Domest Anim, 52:316-326.

Vidane AS, Souza AF, Sampaio RV, Bressan FF, Pieri NC, Martins DS, Meirelles FV, Miglino MA, Ambrósio CE. 2014. Cat amniotic membrane cells are non tumorigenic and safe for use in cell transplantation. Stem Cells Cloning, 7:71-78.

Villaron EM, Almeida J, López-Holgado N, Alcoceba M, Sánchez-Abarca LI, Sanchez-Guijo FM, Alberca M, Pérez-Simon JA, San Miguel JF, Del Cañizo MC. 2004. Mesenchymal stem cells are present in peripheral blood and can engraft after allogeneic hematopoietic stem cell transplantation. Haematologica, 89:1421-1427.

Violini S, Gorni C, Pisani LF, Ramelli P, Caniatti M, Mariani P. 2012. Isolation and differentiation potential of an equine amnion-derived stromal cell line. Cytotechnology, 64:1-7.

Vita BD, Campos LL, Listoni, AJ, Maia L, Freitas NPPF, Lvarenga FL, Prestes NC. 2012. Fetal attachments: an alternative source of mesenchymal ct for equine veterinary medicine [in Portuguese]. Veterinária e Zootecnia, 19:8-22.

Ward DJ, Bennett JP. 1984. The long-term results of the use of human amnion in the treatment of leg ulcers. Br J Plast Surg, 37:191-193.

Wenceslau CV, Miglino MA, Martins DS, Ambrósio CE, Lizier NF, Pignatari GC, Kerkis I. 2011. Mesenchymal progenitor cells canine fetal tissues: yolk sac, liver and boné marrow. Tissue Engineer, 17:21652176.

Yang XX, Xue SR, Dong WL, Kong Y. 2009. Therapeutic effect of human amniotic epithelial cell transplantation into the lateral ventricle of hemiparkinsonian rats. Chin Med J, 122:2449-2454.

You Q, Cai L, Zheng J, Tong X, Zhang D, Zhang Y. 2008.Isolation of human mesenchymal stem cells from third-trimester amniotic fluid. Int $J$ Gynaecol Obstet, 103:149-152.

Zhang S, Guo Y, Cui Y, Liu Y, Yu T, Wang H. 2015. Generation of intermediate porcine iPS cells under culture condition favorable for mesenchymal-toepithelial transition. Stem Cell Rev, 11:24-38.

Zhi-Yuan W, Guo-Zhen H, Yi L, Xin W, Li-He G. 2006. Transplantation of human amniotic epithelial cells improves hindlimb function in rats with spinal cord injury. Chin Med J, 119:2101-2107.

Zuk PA, Zhu M, Ashjian P, De Ugarte DA, Huang JI, Mizuno H, Alfonso ZC, Fraser, Benhaim P, Hedrick MH. 2002. Human adipose tissue is a source of multipotent stem cells. Mol Bio Cell, 13:4279-4295. 